NBER WORKING PAPER SERIES

\title{
KINDLEBERGER CYCLES: METHOD IN THE MADNESS OF CROWDS?
}

\author{
Randall Morck \\ Working Paper 28411 \\ http://www.nber.org/papers/w28411 \\ NATIONAL BUREAU OF ECONOMIC RESEARCH \\ 1050 Massachusetts Avenue \\ Cambridge, MA 02138 \\ January 2021, Revised April 2022
}

This article summarizes the 2012 Heckscher Lecture at the Stockholm School of Economics and the Ratio Institute. Thanks to David Cho for superb research assistance. The views expressed herein are those of the author and do not necessarily reflect the views of the National Bureau of Economic Research.

NBER working papers are circulated for discussion and comment purposes. They have not been peer-reviewed or been subject to the review by the NBER Board of Directors that accompanies official NBER publications.

(C) 2021 by Randall Morck. All rights reserved. Short sections of text, not to exceed two paragraphs, may be quoted without explicit permission provided that full credit, including $\odot$ notice, is given to the source. 
Kindleberger Cycles: Method in the madness of crowds?

Randall Morck

NBER Working Paper No. 28411

January 2021, Revised April 2022

JEL No. G01,G02,G4,N2,O16,O3,O33,O4,P1

\begin{abstract}
$\underline{\text { ABSTRACT }}$
Corporate $R \& D$ has a social return far above its internal rate of return to the innovating corporation, and so is chronically underfunded from a social perspective. Kindleberger cycles, irregularly recurring stock market manias, panics, and crashes, prominent in financial history, are also a major problem for mainstream economics. If manias inundating "hot" new technologies with capital sufficiently counter chronic underinvestment in innovation, economy-level selection may favor institutions and behavioral norms conducive to Kindleberger cycles despite individual agents' losses in panics and crashes.
\end{abstract}

Randall Morck

Faculty of Business

University of Alberta

Edmonton, AB T6G 2R6

CANADA

and NBER

randall.morck@ualberta.ca 


\section{No bubbles in the USSR}

Kindleberger (1978) documents an irregular cycle of stock market manias, panics and crashes from the early 1600 s on. In 2008, Fed chair Alan Greenspan, musing "there were no bubbles in the Soviet Union," suggested this cycle might be unavoidable in prosperous free-market economies ${ }^{1}$ Combining four seemingly unconnected streams of economic research suggests Kindleberger cycles are not merely necessary, but essential to ongoing prosperity.

Economic Growth Theory research shows technological progress, far more than increased inputs, explains rising living standards (Solow 1957). This is because innovation has very large positive externalities: one firm's innovation often opens ways for others (external to the firm) to boost productivity too. Technological progress occurs as successive innovations diffuse across the economy. Innovations with positive externalities spanning the entire economy, called general-purpose technologies (GPTs), can generate vast new wealth (Bresnahan and Trajtenberg 1995; Bekar et al. 2018). Alexander Graham Bell made a decent return on the telephone, but others throughout the economy generated far more by finding valuable uses for instantaneous voice communication (Fischer 1994).

Productivity research affirms that large positive externalities lift innovation's social rate of return $(S R R)$ to the economy far above its internal rate of return $(I R R)$ to the initial innovator (Hall et al. 2010; Jones and Summers 2022). Because profit-maximizing firms only consider their own $I R R \mathrm{~s}$, much high$S R R$ R\&D almost certainly lies latent.

Externality Economics prescribes intellectual property (IP), R\&D subsidies and other interventions to boost innovators' IRRs; however, mounting evidence contests the efficacy of these responses (Jaffe and Lerner 2011). Actual R\&D being a small fraction of socially optimal R\&D is, for mainstream economics, a major market failure.

Behavioral Finance research critiques mainstream economics for providing equations corporations and governments cannot actually use to direct investments in innovation. This disconnect arises because these problems are procedurally transcomputational, meaning no procedure exists for ascertaining the numbers needed to plug into these equations. Behavioral economics shows that, in such situations, people learn by reinforcement, imitate others, and herd - behavior conducive to manias (Shiller 2020).

Financial History research describes irregularly recurring mania, panic and crash cycles in the rise of all major high-income economies. Each cycle begins with a disequilibrium, usually a hot new technology, sometimes a new market, with very high expected IRRs. A mania inflates stocks associated

1 Quoted in Guha, Krishna. 2008. Greenspan urges focus on banks' capitalization, Financial Times May 26, 2008 
with the disequilibrium. A panic, crash, and (sometimes) socially costly economic downturn ensue. Market crashes, for mainstream economics, are another major market failure.

Evolutionary Economics research argues competition culls inefficient institutions. However, tough new regulations enacted after a crash repeatedly fall aside for the next mania (Reinhart and Rogoff 2009; Dagher 2018). Indeed, mania-prone stock markets financed the economic development of one country after another (Rosenberg and Birdzel 1986; Morck and Steier 2005; Demirgüç-Kunt and Levine 2018), including now "bank centered” Germany (Fohlin 2005) and Japan (Morck and Nakamura 2005).

These separate research streams intersect to suggest economic evolution might select for maniaprone stock markets. This might be because Kindleberger cycles draft human behavioral responses to inundate successive nascent technologies with capital, countering otherwise chronic underinvestment in innovation and sustaining the technological progress that underlies economic growth. Mania-prone stock markets may themselves have been a crucial GPT that supports subsequent technological progress. Rather than deplore investor irrationality, policymakers might seek to improve Kindleberger cycles' social benefitcost ratios. Constraining credit expansion during manias sometimes confines crashes within stock markets (Sufi and Taylor 2021), perhaps explaining Samuelson's (1966) reflection “the stock market has predicted nine of the past five downturns." 2

\section{Positive externalities from innovation explain most economic growth}

\subsection{Technological progress explains most economic growth}

By showing that technological progress underlies most economic growth, Solow (1957) founded the field of Economic Growth Theory. ${ }^{3}$ Increased inputs (resources, capital and labor) explain only a small fraction of economic growth in high-income countries. The "unexplained" greater part, called the Solow Residual, reflects productivity growth: successive new technologies displacing older ones, each producing highervalued output from given inputs. Tracking expanding Solow Residuals with various productivity growth measures has become a major focus of policymakers and economic researchers (Jones and Summers 2022). Figure 1 shows Solow residuals, approximated by cumulative multifactor productivity growth, larger where private-sector $\mathrm{R} \& \mathrm{D}$ is larger.

This is good news, in that ongoing prosperity depends on potentially unlimited new ideas, more than limited tangible inputs. Although Gordon (2016) concludes innovation is slowing, Mokyr (2018) reports the pace of innovation repeatedly falling and rising again. Trajtenberg (2018) and Choi (2018) see

Newsweek, Sept. 9, 1966.

Akcigit and Nicholas (2019) He and Tian (2020) provide comprehensive surveys. 
machine learning and 3D printing as nascent technologies with vast potential to increase productivity.

\subsection{Chronic underinvestment in innovation}

Productivity Economics research shows corporate R\&D having IRRs of 10 to $15 \%$ for the innovating firm and $S R R$ s well over $40 \%$ for the overall economy. ${ }^{4}$ The $S R R$ minus $I R R$ gap varies across industries and over time. Griliches (1957) estimates $S R R$ s of agricultural innovations at 35 to $40 \%$ versus a $10 \% \operatorname{IRR}$ benchmark. Subsequent work, reviewed by Hall et al. (2010), affirms innovations having SRRs manifold higher than their 10 to $15 \%$ IRRs. Bloom et al. (2013) identify an SRR of R\&D of 59\% using US states' changes in R\&D taxes. Acharya (2008) finds the $S R R$ of R\&D exceeding its $I R R$ by 90 to $101 \%$ in pharmaceuticals and by 49 to $62 \%$ in computers, but by little if anything in general machinery and equipment. Jones and Summers (2022) conclude that "under conservative assumptions, innovation efforts produce social benefits that are many multiples of the investment costs."

Figure 2 summarizes social and private returns to R\&D from Lucking et al. (2019). ${ }^{5}$ Profitmaximizing firms undertake R\&D whose $I R R$ exceeds its cost of capital, $k$. Plausible $k$ estimates range from the riskfree rate $r_{f}$ to $r_{f}$ plus various multiples of the market risk premium. ${ }^{6}$ The lower bound is near zero in recent years, the upper bound is in the $10 \%$ to $15 \%$ per year range, not far below the ranges for the private returns on R\&D. In stark contrast, the $S R R$ s of $R \& D$ range from $60 \%$ to $80 \%$ per year; rising in the early 1990s, as IT innovations diffused, falling from the mid-1990s on as capital flooded in, and then stabilizing after the 2000 crash. Despite their large confidence intervals, social returns far exceed private returns and plausible costs-of-capital. That is, $\mathrm{R} \& \mathrm{D}$ is marginally profitable to innovating firms and manifold more valuable to the economy as a whole.

Firms acting for society would do all R\&D projects with $S R R>k$, not just those with $I R R>k$. Scherer (1999) concludes much high $S R R$ R\&D has quite low, and even negative, IRRs. This is a major

4 Jones and Summers (2022) provide a survey and discussion of estimation procedures.

5 Lucking et al. (2019) do not estimate IRRs directly, but use the methodology of Bloom et al (2013), whose online appendix relates this to $I R R \mathrm{~s}$ in an intertemporal model.

6 To a first approximation, $k$ is the return investors would require from the project were it a freestanding equityfinanced firm. The capital asset pricing model defines $k=r_{f}+\beta \lambda$ with $r_{f}$ the return investors require on riskfree investments, $\lambda$ the risk premium diversified investors require from the stock market as a whole, and $\beta$ the project's risk to diversified investors relative to that of the market as a whole. T-Bond rates, the US government's long-term borrowing costs proxy for $r_{f}$. Damodaran (2014) provides historical $\lambda \mathrm{s}$. Welch (2020) provides $\beta$ s for US stocks. Innovation is risky but, at least early on, also highly idiosyncratic (Pástor and Veronesi 2009), with successes cancelling failures. Consequently, some R\&D can be essentially riskfree $(\beta=0)$ to diversified investors (Jørring et al. 2017). Systematically riskier R\&D requires $\beta>0$. Welch's $\beta$ s never exceed four and $98.4 \%$ are below two. Consequently, $k$ ranges from $r_{f}$ to $r_{f}+4 \lambda$, with most below $r_{f}+2 \lambda$ and many perhaps near $r_{f}$. Evens et al. (2014) argue idiosyncratic risk can raise venture capital costs above these benchmarks. Kogan and Papanikolaou (2019) review related work. 
market failure: market forces generate R\&D chronically and profoundly short of what socially optimal R\&D would be.

\subsection{Government interventions to encourage innovation often work poorly}

Externality Economics (Pigou 1920) prescribes policy responses to such market failures, but each response begets problems. ${ }^{7}$ Intellectual property (IP) law can strengthen and lengthen patents and copyrights, raising a firm's IRR from any given innovation, but may not accelerate aggregate innovation (Brown et al. 2017). First, larger or longer streams of profits from one innovation make finding another less urgent. Second, stronger IP for initial innovators limits spin-off innovations by others (Caballero and Jaffe 1993). Third, patent trolls "game" IP, accumulating patents someone might someday infringe. A \$612.5 million lawsuit for violating a troll's "wireless e-mail" patent crippled Blackberry, a smartphone pioneer (Sweeny 2009). Accumulating evidence suggests intense political lobbying (Saperstein 1997; Drahos 2003) has increasingly reshaped US IT law to impede, more than encourage, innovation (Jaffe and Lerner 2011).

A second policy response is state-subsidized R\&D. ${ }^{8}$ Zúñiga-Vicente et al. (2014) summarize research into these policies as "inconclusive" and reflecting "rising concern about the effectiveness of public subsidies." Two patterns are noteworthy: First, unlike private-sector R\&D in Figure 1, public sector $R \& D$ is not clearly correlated with productivity growth (e.g. OECD 2003). Second, state-financed R\&D appears to have lower IRRs and SRRs than private-sector R\&D (Hall et al. 2010).

Several explanations are proposed. State-funded basic science R\&D may have hard-to-measure social returns that spill over borders, take decades to commercialize, or advance life quality rather than GDP (Ahmadpoor and Jones 2017; Azoulay et al 2019, 2021). Other explanations allow less sanguinity. As thermodynamics arose to explain working steam engines (Gillispie 1960,357), some basic research may explain, not inspire, new technology (Edgerton 2004). Corporations, universities, and labs patent statesubsidized R\&D, so dysfunctional IP law remains problematic (Lach and Schankermann 2004). Cashstrapped universities, selling state-subsidized patents, may even fatten patent trolls (Watkins 2014). Government officials have difficulty "picking winners" to subsidize (Lerner 2009), even in Japan (Beason and Weinstein 1996). Bureaucrats may find more bureaucratic applicants' perfectly filled-out proposals more convincing (Jaffe 1989) and influential lobbyists' applications worthier (Lerner 2009) than those of actual innovators. Misgoverned universities may misallocate research funding (Goulsbee 1998; Sokal and

7 Externalities occur whenever one party's actions affect other's welfare. Negative externalities, e.g. one firm's pollution harming others, enters corporate social responsibility rankings. Positive externalities, e.g. one firm's innovation benefiting others, typically do not. On problems with policy responses, see Goolsbee and Jones (2022).

8 Yet other interventions - governments offering prizes for new technologies (Wright 1983) or buying patents and making technologies free (Kremer 1998) - are complicated by incentive problems (e.g. Ales et al. 2017). 
Bricmont 1999; Strevens 2013; Ioannidis et al. 2014), including in economics (Kwak 2017). Statesubsidized $\mathrm{R} \& \mathrm{D}$ at large corporations, universities, and government labs may even draw talent away from innovative new firms' higher SRR R\&D efforts (Goolsbie 1998; Lach 2002).

\section{Behavioral Economics explains investment in innovation}

Corporations and governments contemplating R\&D spending confront effectively insolvable problems. Behavioral Finance research explores people's behavior in such situations. ${ }^{9}$

\subsection{Rational agent economics meets procedurally transcomputational problems}

Actual decision-makers can find economists' expectations of rationality daunting. Economics deems an investment viable to a firm or worthy of state subsidies if the IRR or SRR, respectively, exceeds a threshold; and provides exact equations for both problems. Retrospectively, roughly estimating an R\&D project's $I R R$ or $S R R$ is possible, but subject to wide margins of error, as in Figure 2. When decisions are made, prospectively predicting $I R R \mathrm{~s}$ requires hundreds of numbers: prices and quantities of all inputs and outputs and taxes due in every future time period and state of the world, and the probabilities of each state of the world in each time period. ${ }^{10}$ Predicting SRRs requires all these plus social values of all externalities. A few of these numbers are unreliably guestimatable; most are fundamentally unknowable.

Told to evaluate an investment project, students are given all these numbers (or abstract assumptions about them) and then As for solving the equations. Alumni actually have to find meaningful values to plug in. Experience fills in some numbers and justifies assumptions for familiar repeated investments. However, innovations are literally new; their prospects often unknowable. Keynes' (1936) conclusion "human decisions affecting the future, whether personal or political or economic, cannot

9 For a general survey, see Hirschleifer (2015).

10 Business schools teach students to calculate a project's IRR by solving

$$
-K+\sum_{s=1}^{S} \sum_{t=1}^{T} \pi_{s, t} e^{-I R R \times t}\left(\sum_{m=1}^{M} p_{m, s, t} q_{m, s, t}-\sum_{n=1}^{N} p_{n, s, t} q_{n, s, t}-\tau_{s, t}\right)=0
$$

plugging in its setup cost $K$, prices $p_{m, s, t}$ and quantities $q_{m, s, t}$ of each of its $M$ outputs, prices $p_{n, s, t}$ and quantities $q_{n, s, t}$ of each of its $N$ inputs (raw materials, intermediate goods, and categories of employees, for example), taxes due $\tau_{s, t}$, all in every future time $t$ in every possible state of the world $s$, and the probabilities $\pi_{s, \tau}$ of the world being in possible each state $s$ at each future time $t$. Relating each output to its required inputs also requires knowing the $M$-dimensional time and state-dependent production function $q_{m, s, t}=f_{m, s, t}\left(q_{1, s, t} \ldots q_{n, s, t} \ldots q_{N, s, t}\right)$. The $I R R$ is then compared to a cost of capital, obtained by predicting the project risk consequences to a diversified investor.

To calculate a project's social rate of return, officials are to find the $S R R$ that solves

$$
-K+\sum_{s=1}^{S} \sum_{t=1}^{T} \pi_{s, t} e^{-S R R \times t}\left(\sum_{l=1}^{L} x_{l . s . t}+\sum_{m=1}^{M} p_{m, s, t} q_{m, s, t}-\sum_{n=1}^{N} p_{n, s, t} q_{n, s, t}-\tau_{s, t}\right)=0
$$

the $x_{\text {l.s.t }}$ being social values, positive or negative, of all its externalities in each possible probability-weighted states of the world at each future time and all other variables as in the IRR equation. Even in estimating past private and social returns, only very rough approximations are econometrically feasible. Accurately assessing future private and social returns of current investments is highly problematic, especially for investments in innovation. 
depend on strict mathematical expectation, since the basis for making such calculations does not exist" surely applies to innovations. The more profound the innovation, the more distant the time horizon, the deeper our current ignorance, and the more outrageous the conceit that our equations provide solutions. Keynes' critique is frequently elaborated and acknowledged (e.g. Simon 1957; Nelson and Winter 1982; King and Kay 2020), but business students nonetheless memorize ever more intricate equations.

Mathematical problems whose solutions must exist, but require impossible computing power, are called transcomputational (Bremermann 1962). Grossman and Stiglitz (1980) distinguish substantive rationality, the optimization of standard economic theory, from procedural rationality, the optimization of the decision-making procedure itself. Extending this distinction, a problem is procedurally transcomputational if an equation provides its solution, but no procedure for finding numbers to plug into that equation exists. ${ }^{11}$ Equations for making R\&D investment and subsidy decisions easily qualify.

\subsection{How behavioral economics inundates innovations with capital}

Confronting procedurally transcomputational problems, people use Simon's (1957) bounded rationality. New problems evoke memories of similar problems and of experienced or observed responses. Stimulusresponse pairings, called heuristics, that worked well are remembered and imitated (Bordalo et al. 2021).

Successful heuristics spread and displace less successful ones (Nelson and Winter 1982; Kahneman 2011). Behavioral economics characterizes heuristics as biases, but King and Kay (2020) reject this term where procedurally transcomputationality leaves unbiased behavior undefinable. ${ }^{12}$ Rather, economic selection, like evolutionary algorithms in machine learning, selects for heuristics with ever better outcomes (Lo 2019; Lo and Remorov 2021). Economic selection may thus do what economic rationality cannot: "defeat the dark forces of time and ignorance which envelop our future," Keynes' (1936) definition of investment success.

The heuristic "imitate those who likely know what to do" has survival power. It is readily elicited in laboratories, evident in many real settings, and resonant with a human propensity to conform (Hirshleifer 2015, Bikhchandani et al. 2021). It persists because it often seems successful, but it can also cause overreactions in ways that plausibly drive Kindleberger cycles. Early highly publicized successes investing in big new technologies, whose valuations are procedurally transcomputational, can evoke expanding rounds of imitation. Early success stimulates more investment, which lifts stocks, reinforcing perceptions of success, and stimulating yet more investment. Called information cascades, such feedback loops can

11 This differs from ambiguity models (Epstein and Schnweider 2021), wherein agents know all parameters except state probabilities, to which can be affixed multiple prior mathematical probabilities.

12 Kahneman (2011) and Hirshleifer (2015) review this literature. 
inflate securities prices in bubbles that ultimately burst. Bikhchandani et al. (2021) review this literature.

Rational investors who realize a bubble is inflating are caught in what Keynes (1936) calls an investment beauty contest.

"It is not a case of choosing those [faces or investments] that, to the best of one's judgment, are really the prettiest, nor even those that average opinion genuinely thinks the prettiest. We have reached the third degree where we devote our intelligences to anticipating what average opinion expects the average opinion to be. And there are some, I believe, who practice the fourth, fifth and higher degrees."

Rational investors (if any exist) seek to buy stocks they expect heuristic-driven investors will soon deem more beautiful. Owning what others deem beautiful can also convey social status, further strengthening the positive feedback (Veblen 1899). Stock market investing provides randomized rewards, especially conducive to reinforcement learning (Smith et al. 2014). Information cascades, turbo-charged by these effects, can escalate stock prices and inundate firms in sectors associated with high-profile innovations. Paying extra taxes to finance state-funded innovation, has no comparable allure.

\subsection{The social value of capital inundations}

Bubbles thus flood capital across innovations rational investors would shun; and in volumes government programs could not match. ${ }^{13}$ After the flood abates, the crash harms small investors, corporate acquirers (Moeller et al. 2005), and even venture capitalists (Kerr et al. 2014). But the technological progress that capital funded, and its large positive externalities, remain (Angeletos et al. 2010). The Crash of 1929 destroyed the wealth of investors in electric power grids, but the power grids remained. The 2000 crash erased the wealth of dot.com investors, but the internet remained.

This may have special relevance for GPTs positive network externalities (Katz and Shapiro 1985; Liebowitz and Margolis 1994). Recall that network externalities increase the value of an innovation as more people adopt it: a telephone is a poor investment if yours is the only one, but grows increasingly valuable in an expanding telephone network. Rational agents in mainstream economics avoid such investments because they cannot ensure others will invest too. However, a Keynesian beauty contest generates just the sort of leap of faith necessary to roll out innovations with large network externalities.

If manias have these sorts of social benefits and if they outweigh the social costs of panics and crashes, economists' scolding of bubble investors for irrationality may be overwrought (MacKay 1841;

13 Dicks et al. (2021) and Janeway et al. (2021) survey Behavioral Finance work on investment booms in innovation during bubbles. See also Frydman and Goldberg (2011) and Janeway (2018). 
Cole 1720; Chancellor 1999; Reinhart and Rogoff 2009; Goldfarb and Kirsch 2019). Financial history illuminates this trade-off.

\section{Bubbles for Needham?}

Two puzzles prominent in Financial History research help organize the above issues. The first is Needham's (2004) question "Why did the West, and not China, get rich first?" (Shin 2018). The second is that irregularly recurring stock market bubbles are historically associated with surges in innovation and prosperity (Janeway 2018; Aliber and Kindleberger 2015).

\subsection{Needham's Question}

Until recent centuries, almost everyone everywhere lived in indistinguishably abysmal poverty (Bolt and Van Zanden 2020). Then, beginning in the early 1600s, country after country escaped poverty (Deaton 2013). Science historian Joseph Needham (2004) documents China's historic technological superiority and asks "Why wasn't China first?"

Baumol (1990) describes major Chinese innovations sitting unused until rediscovered in the West; and argues initially uniquely Western institutions encouraged these innovations' applications in business. Incomplete answers include capital from natural resources or its absence (Sachs and Warner 2001; Morck and Nakamura 2018), capital from imperialism-plus-slavery (e.g. Baptist 2014), and the patent, invented in renaissance Venice (Landes 1998). But abundant (or absent) natural resources are not unique to the countries that escaped; nor are imperialism and slavery; and Moser's (2018) concludes patents have, at best, an ambivalent contribution.

Rosenberg and Birdzel's (1986) finding that countries escaped poverty in step with the local rise of stock market financing, may point to a fuller answer to Needham. Stock markets let Kindleberger Cycles intermittently flood hot new technologies with capital, create positive externalities, and lift country after country out of poverty. This section reviews research specifically relevant to this hypothesis.

\subsection{The first stock market and the first mania}

In the early 1600s, new mathematics revolutionized oceanic navigation (Davids 2015, Levy-Eichel 2015). Amsterdam navigation schools taught Mercator projections, trigonometry, logarithms and slide-rules. Their alumni were the era's high-tech stars. Amsterdam also organized the modern world's first stock market to trade shares in the Dutch East Indies Company, whose spice trade made the city an entrepôt to other parts of Europe (Frentrop 2002). The stock market soon capitalized other companies that, using the new mathematics, moved high value-added goods (including slaves) across oceans.

The first bubble also formed and popped in Amsterdam. By 1637, Dutch East Indies stock was up 
over 250\% (Petram 2011, p. 297), oceanic trade investors were rich, and speculative investors sought high returns elsewhere. A prominent bubble arose in tulips, a status luxury good. In the 1630s, tulip prices soared and derivative securities priced notional tulips in quantities far outstripping their physical numbers. Tulips crashed in 1637, ruining speculators (scolded by moralists of subsequent ages), but leaving the economy largely undamaged (Goldgar 2008). Stocks recovered and resumed rising (Petram, 2011, p. 98). The minuscule but technologically advanced Netherlands, for a time, became a world power.

\subsection{The first international mania}

The 1688 Glorious Revolution, a Dutch intervention to oust Britain's Catholic king, brought "Dutch Finance" - stock markets and joint-stock companies - to London (Frentrop 2002; Barone 2007). Late 17 and early $18^{\text {th }}$-century British shareholders avidly bought tech stocks in oceanic trading, steam engine pumps, and gas lights. Edmund Halley's actuarial tables formalized risk-reward trade-offs and revolutionized insurance.

As stocks rose, a wave of IPOs floated trading, mining, manufacturing, mortgage, real estate, and pseudo-high-tech companies, including possibly apocryphal “element transmutation' and "wheel of perpetual motion" firms (Mackay 1841). Stocks rose in London, Amsterdam (Frehen et al. 2013), and Paris, where the Scottish escaped murderer John Law organized a stock market for his Mississippi Company (Murphy 2005). The fraudulent nature of Law's company, and of John Blunt's South Seas Co. in London (Balen 2002), brought on the Crash of 1720, ruining small investors in all three markets.

But afterward, Britain had oceanic trading, insurance, mining, steam pumps, and other new technologies (Carswell 1993). Britain also have a disruptive class of Whigs who "raised themselves from poverty to great wealth" (Davenant 1701) and pressed for liberal reforms. Britain's 1720 Bubble Act, requiring parliamentary charters for IPOs, lost traction over time as such charters become routine. The Netherlands also recovered, but France continued suppressing its stock market longer and harder and fell behind.

\subsection{New technology manias throughout financial history}

Subsequent bubbles financed successive new technologies. In the 1790s, British investors took to canals. Canal stocks rose and collapsed several times, but by the 1810 s Britain's canal network connected previously isolated inland regions to ports. In the 1820 s, new mining and textiles technologies lifted stock prices. In January 1825 alone, seventy IPOs debuted. Speculation spread to bonds of the newly independent Latin American republics, each touted as the "next" USA. Stocks crashed in December 1825 (Dagher 2018) and a Latin American debt crisis ensued. But the new technologies remained and the new republics were established. Another canal bubble burst in 1836 in Britain and 1837 elsewhere, but left canal networks in 
America and Canada too.

A railway bubble burst in 1847 in Britain and 1848 elsewhere (Campbell 2012, 2013), but left railways throughout Britain, Europe, Canada and the US. A European bubble burst in 1857, but left industrial plant in place. Waves of breakthrough patents in the 1860s and 1880s (Kelly et al. 2021) heralded bull markets that crashed in 1873 and 1893, each leaving new technology-improved railroads, telegraph systems among the most important. The US emerged as a major economic power. Rapid settlement in southern Latin America pulled in capital and a second Latin American debt crisis in 1890 nearly destroyed Barings Bank.

Rising stocks from the mid-1890s into the early 1910s financed new technologies in cement, petroleum, steel, telephones, and electric lighting, equipment, and transportation (Osullivan 2007). Stocks crashed and recovered as capital poured into Australia, Canada, Japan, Germany, Scandinavia, and the US. Each crash destroyed shareholder wealth, but left industrialized economies.

The Roaring 1920s bubble (Nicolas 2007) lifted -tech stocks such as Radio Corporation of America (radio), International Business Machines (adding machines), General Motors (automobiles), PanAm (airfreight), and RKO (motion pictures). Stock-financed electricity and telephone networks brought network externalities. Stocks crashed in 1929, but left all these new technologies in place. Sometimes under new ownership, tech firms continued making major advances into the 1930s (Field 2003, 2011).

Tech bubbles also arose in the 1960s and 1990s. The 1960s bull market ended with a large real drop in stock prices, partly obscured by the high inflation of the 1970s, but left aerospace, mainframe computers, passenger jets, plastics, solid-state electronics, plastics, and synthetic fabrics. The 1990s dot.com bubble ended with the Crash of 2000, but left cell phones, the internet, microcomputers, and software that increased productivity, including in many established industries.

\subsection{Big new markets resemble big new technologies}

Kindleberger (1978) reports most manias developing around new technologies, but some arising around promising new market economies: new Latin American republics in the 1820s; East Asian Tiger Economies in the 1990s. Rosenstein-Rodan (1943) explains that economic development itself has huge network externalities. Like a telephone, a factory in a subsistence economy is an iffy investment if yours is the only one. A factory needs competing potential suppliers and customers, which all need their own competing suppliers and customers. Each new firm helps fill out the network and make existing firms more viable.

Like patents and subsidies as innovation drivers, industrialization planning and foreign aid are problematic drivers of economic development (Easterly 2006). Here too, bubbles may succeed where bureaucrats and subsidies fail. Hirano and Yanagawa (2016) show country-level bubbles drawing capital 
into promising middle-income economies, but rarely into low-income economies. Allen (2001) argues a threshold of domestic financial development is necessary for a bubble to form. Like the new technologies left in place after a tech bubble, the physical assets put in place during a country mania remain to offset costs of the panic and crash.

\subsection{Kindleberger Cycles draft one market failure to defeat another}

Kindleberger (1978) discerns a common pattern in this centuries-long irregular cycle of manias, panics, and crashes. Figure 3 summarizes, drawing connections to the research discussed above.

First, a big new technology, such as the internet, or (less often) a big new market, causes a disequilibrium. With prices and costs misaligned, a few clever or lucky firms and investors earn large positive economic profits.

Other investors, finding valuing new technologies or markets procedurally transcomputational, mimic successful investors. Grappling with intrinsically unsolvable valuation problems, investors disagree and highest bids set prices (Hong and Stein 2007). As positive externalities spread, so does harmonious investor optimism (Pástor and Veronesi 2009). Information cascades arise (Angeletos et al. 2010). Adapting firms expand and proliferate as capital floods in. Demand lifts their shares, further increasing investor demand. This positive feedback characterizes the cycle's bubble stage.

Credit expansion and deregulation ensue. Credit expands as investors borrow to invest even more. Small investors clamor for deregulation to get a piece of the action. Akerlof and Shiller (2010, p. 154) attribute US deregulation prior to 2008 to a "belief that the opportunities to take part in the housing boom were not being shared fairly." These effects are more extensive in some cycles than others. Small shareholders borrowed heavily in the 1920s bubble, but not in the 1990s bubble.

Kindleberger (1978) calls the next stage, the instant of collective insight that stocks are celestially overvalued, the Minsky moment, honoring Minsky's (1986) observation that bubbles burst on days of little or no other news. Many forces combine to delay Minsky moments. Creative accounting touches up financial reports, larger frauds obscure earlier rule-bending. Financial engineers help with new ways of disguising high leverage, the conventional way of jacking up returns (Geanakoplos 2010). Deregulation and monetary expansions that prolong credit expansion keep bubbles inflating. Sometimes, a second Minsky moment is needed. After one market crashes, investors seek high returns elsewhere. Spin-off bubbles, often in highly leveraged real estate, inflate and, after their own Minsky moments, pop.

A panic and crash ensue. Investors, fearing others fear that others no longer deem stocks beautiful, rush to sell first, before prices fall. All investors running to sell first, a market run, crashes stocks (Bolton et al. 2011). If enough investors who borrowed to buy into the bubble then default, stressed financial 
institutions curtail regular lending and a recession ensues (Rerinhart and Rogoff 2009).

A clean-up stage follows. Frauds are exposed. Political calculations press governments and central banks to bail out large banks and firms. To pay for bailouts, governments hike taxes, print money, and borrow, sometimes risking their own financial stability. Free market economics looks tainted. Angry voters demand tough new regulations. Pundits elegize capitalism.

A secular stagnation era of sedate near-equilibrium growth follows, paying investors equilibrium returns (Gordon 2015). Over time, regulators succumb to lobbying (Stigler 1971); ex-innovators become entrenched monopolists; and the end of progress is proclaimed (Horgan 1996; Gordon 2016).

After an irregular interval, another dislocation initiates a new Kindleberger cycle. Forgetting the misfortune of their elders, or former selves, people in high-income economies have been repeating this cycle for four centuries. This is no cause for despair if each cycle lifts productivity, if not stocks, to a new permanently higher plateau. Bubble investors' private losses are laudable sacrifices to enrich the economy.

\section{Evolutionary economics and selection for Kindleberger Cycles}

Research in Evolutionary Economics, which replaces the rational maximization assumptions of mainstream economics with trial and error plus the survival and spread of whatever works best, provides a way to combine the above streams of research to answer Needham's question. ${ }^{14}$ Economic selection is uncontroversially multilevel - simultaneously between individuals, firms, and economies. For economylevel selection to favor institutions prone to Kindleberger cycles, their social benefits must exceed their social costs. If investors who lose in bubbles are nonetheless better off by living in such an economy, the case is even firmer.

\subsection{Social gains as manias fund innovation}

Evidence that bubbles have social benefits is accumulating. ${ }^{15}$ Stock market bubbles coincide with sharply elevated corporate investment (Martin and Ventura 2018), especially by firms with more important patents (Haddad et al. 2020). This encourages CEOs to direct more investment to hot technologies (Dang and Xu 2018). Option valuation effects can also elevate tech stocks (Kerr et al. 2014), drawing in more capital. Innovations financed in the 1920s (Field 2003, 2011; Nicholas 2008) and 1990s (Dang and Xu 2018) bubbles are atypically important, implying larger positive externalities (Kogan et al. 2017; Shin and

14 Nelson et al. (2018) provide an overview of Evolutionary Economics. See Lo (2019) and Lo and Remorov (2021) for aspects of that field associated with finance.

15 Macroeconomics (Martin and Ventura. 2018; Simsek 2021) and finance (Jarrow 2015, Dicks et al. 2021) are rethinking bubbles, long deemed growth inhibiting. If underwriting fees, information costs or other frictions reduce corporate investment, bubbles that increase investment can have ambiguous growth implications. This revisionism is not universally accepted. Bosi and Pham (2016) propose taxing bubbles to subsidize innovation. 
Subramanian 2019). Martin and Ventura (2010), Tanaka (2011), Lansing (2012), and Takao (2017) model bubbles easing financing constraints and promoting investment. Eatwell (2004) describes bubbles allocating capital to profitable investments left unfunded by capital rationing or managerial myopia and to unprofitable investments with large positive externalities.

During bubbles, R\&D rises more than capital investment (Dang and Xu 2018). R\&D-intense firms, often young and without earnings histories or collateral, cannot borrow and therefore rely on stock markets (Brown et al. 2012; Hsu et al. 2014; Acharya and Xu 2017). Such firms are exceptionally likely to list and issue more shares during bubbles (Brown et al. 2009; Aghion et al. 2012) to fund current and future R\&D (Brown et al. 2009, 2012; Brown and Petersen 2011). As the bubble expands, takeovers of tech firms enrich their founders (Phillips and Zhdanov 2013). Early 20 th century inventors (Nicholas 2010) and late $20^{\text {th }}$ century venture capitalists and IT entrepreneurs (Gompers and Lerner 1999) often listed and sold to acquirers, locking in high returns for themselves and leaving the crash to others.

Flooding capital across whole sectors or economies allocates capital indiscriminately, not precisely. Still, Ashton (1948, p. 83-4) concludes that, although the British canal mania of the late 1770s "undoubtedly led to some waste of national resources," its benefits were greater because "agricultural regions which had been remote from the center were brought within the widening circle of exchange; the fear of local famine, of both food and fuel, was removed; and the closer contact with others, which the new means of communication afforded, had a civilizing influence." Given the very high $S R R$ s of innovation, precisely targeted chronic underinvestment is not obviously socially preferable to indiscriminate abundant investment.

\subsection{Sandbagging stock markets to contain social costs}

If the panic and crash end the story, stock market investors are poorer but the wealthier economy moves on. If a financial crisis or major downturn ensues, social costs are larger. Financial crises worsen health outcomes, trust in institutions, and political polarization and reduce long-run trend GDP by two to ten percent (Sufi and Taylor 2021). More credit expansion during the mania heralds worse crises and downturns (Rerinhart and Rogoff 2009; Greenwood et al. 2020; Sufi and Taylor 2021).

More lending to mania investors leaves lenders' balance sheets heavier with nonperforming loans after the crash. This can trigger a chain reaction. Financial institutions, hoarding cash to rebuild their balance sheets, curtail normal lending to fundamentally sound firms. Fundamentally sound firms halt investment, downsize, or even fail; laid-off workers default on loans, financial institutions' balance sheets weaken further, and the downward spiral intensifies. Financial institutions without deposit insurance fear bank runs (Diamond and Dybvig 1983), all their depositors running to withdraw their savings before the 
institution fails, which cause those institutions to fail.

To prevent these outcomes, governments regulate banks and financial institutions to limit risky credit expansions. However, these regulations often falter as manias intensify (Jorda et al. 2013; Fahlenbrach et al. 2018; Krishnamurthy and Muir 2016). Regulators limiting credit to avid investors find little political support and shadow banks, outside the gambit of bank regulators, arise to do what banks cannot. Bankers, losing business, lobby for deregulation. Like investors, government officials confronting procedurally transcomputational problems follow the herd (Bošković et al. 2013) and deregulate.

After crashes, governments bail out banks and shadow banks to prevent worse damage from a deeper financial crisis (Bernanke 1983). However, bailouts are expensive. Lucas (2019) puts 2008 US bailout costs at 3.5\% of GDP. Kaminsky and Reinhart (1999) put mean bailout costs in financial crises at $5 \%$ to $13 \%$ of GDP. Overall, financial crises' macroeconomic costs, assessed as pre-crisis trend GDP growth minus actual GDP growth, range from 2.4 to $20 \%$ of GDP, with most clustering in the lower range. ${ }^{16}$ However, these estimates overstate social costs if, without Kindleberger cycles, baseline GDP growth would have been far lower.

\subsection{Secondary bubbles often have net social costs}

Bubbles can ferment more bubbles. Bubbles spread from stock market to stock market, and to real estate and even consumer goods. Kapeller and Schütz (2014) argue high returns in technology bubbles increase inequality and spending on goods that signal high social status (Veblen 1899). Shiller (2020) suggests hot technology goods of their eras, - telephones, automobiles, cellphones, or Bitcoins - confer status, which increased demand for them, further increasing their prices and their Keynesian beauty (status goods signal status because others believe they do). Bubbles in status-signaling high-tech goods can thus also draw yet more money into innovation.

Other status good bubbles are not obviously socially beneficial. Status-seeking bourgeois investors in 1630s Holland, enriched from investing in oceanic shipping, bid up tulip prices. A bubble in Beanie Babies, a pricy toy, expanded and popped alongside 1990s tech stocks (Bissonnette 2016). Neither has obvious positive externalities.

Rising inequality can likewise inflate real estate, pricy properties being another status good. Real estate bubbles have major social costs because banks and other financial institutions routinely accept real estate as collateral for loans. Credit therefore readily expands as real estate bubbles inflate. Chen and Wen (2017) describe initially high network externality returns falling as China's network of suppliers and

16 Sufi and Taylor (2021) review this literature, as well as financial crises associations with increased health problems, mistrust in institutions, and political polarization. 
customers filled out; and investors seeking continued high returns inflating a real estate bubble. Secondary real estate bubbles also accompanied rollouts of canal, railway, telegraph, and electric power networks. The 2008 financial crisis was plausibly secondary to the 1990s tech bubble. To stimulate their economies after stock market crashes, central banks often cut interest rates, potentially encouraging socially costly credit-fueled real estate bubbles in the wake of socially useful tech bubbles.

\subsection{Social summations}

Economic comparisons of these social gains and losses are remarkably rare. Lansing (2009) finds the social benefits of increased investment exceed the social costs of increased volatility from bubbles. Lansing (2012) models tech bubbles with costly crashes and calculates social benefits outweigh social costs if the technology's $S R R$ exceeds 2.5 times its $I R R$. Section 2.2 suggests $S R R$ s of corporate R\&D exceed this. Historians (Perez 2002; Gross 2007; Janeway 2018) and, with considerable sophistication, marketing researchers Sorescu et al. (2018) also conclude the social benefits of bubbles exceed their social costs.

Credit expansion can upset this balance. Larger credit expansions during manias can deepen capital inundations, financing more innovation, but also leave worse cleanup costs. Olivier (2000) models stock market tech bubbles as productivity-enhancing and credit expansion bubbles as productivity-diminishing. Janeway (2018) moves beyond a simple dichotomy, allowing credit expansions to magnify tech bubbles, and even boost innovation by boosting aggregate demand. Nonetheless, crashes that leave credit-granting institutions with large non-performing loan portfolios herald financial crises and protracted downturns (Aliber and Kindleberger 2015; Reinhart and Rogoff 2009).

Regulations that keep credit from deepening capital floodwaters during manias might therefore help make Kindleberger cycles more socially beneficial. Regulations enacted after a crash sometimes have this objective, as when the US imposed margin requirements on stock market investments after the 1929 crash. But post-crash regulations are in most cases hasty, readily eroded (Dagher(2018) and even, in the case of short-sale restrictions, conducive to the next manias (Hong and Stein 2007). This requires explanation.

\subsection{Suspending Cardwell's Law}

Cardwell's Law (1972, p. 210) is the historical regularity that societies are technologically innovative only briefly. Innovators are often political outsiders. Rapid innovation threatens the positions of individuals, firms and communities with old-technology skills or assets, who are often politically well connected. Schumpeter (1911) warns innovators of ostracism, condemnation, and even violence. Opponents of innovation, from $18^{\text {th }}$ century Luddites to $21^{\text {st }}$ century anti-GMO activists (Mazur 1975; Jones 2013; Juma 2016) successfully slowed innovation (Mokyr 2000; Wu 2010; Jaffe and Lerner 2011). 
Opposing innovation may resonate with basic behavioral heuristics. Prospect theory shows people fear losses more than they value gains of equal magnitude (Kahneman and Tversky 2013). This may have roots in Edmund Burke's (1790) precautionary principle, survival is precarious, and change with even a minuscule risk of disaster is unwise, which motivates both political conservatism and environmental conservationism.

Kindleberger cycles may defeat Cardwell's Law by mobilizing offsetting heuristics: fascination with novelty, success emulation, and comfort in following the herd. Novelty activates the brain's dopamine system: intermittent success, repeated or observed, elicits more repetition, optimism, and thus bubbles (Hirshleifer 2015; Bikhchandani et al. 2021). Early movers' highly visible disequilibrium profits cue investors and CEOs into financing cascades of additional investment in similar things.

Group-level natural selection can favor novelty-seeking if, for example, lives saved by an expanded food supply exceeded deaths from tasting unfamiliar plants (Wilson and Wilson 2008; Williams and Taylor 2006), perhaps explaining investor excitement with new technologies (Galor and Michalopoulos 2012). A "disposition to admire, and consequently to imitate, the rich and the great" (Smith 1759) also has plausible survival value (Gibson and Hoglund 1992; Blackmore 1999, pp. 74 - 81; Bikhchandani et al 2021) and may explain uninformed investors imitating successful investors (Bikhchandani et al. 2006). A "fear of missing out" may reinforce this (Janeway 2018; McGinnis 2020). Success begets optimism and emotional contagion (Barsade 2002) underlies Keynes' (1936) theory of animal spirits-driven stock markets.

Economies with institutions that enlist these behavioral regularities to power Kindleberger cycles may, despite suffering panics and crashes, outcompete other economies by defying Cardwell's Law. This perhaps explains high-income economies chronically failing to retain laws that suppress Kindleberger cycles. Economies that successfully upheld such laws would cease being successful.

\subsection{Economic selection for Kindleberger Cycles}

Mokyr (1994) posits economic selection favoring economies that escape Cardwell's Law and sustain ongoing innovation. Economic selection being multilevel, fast and discrete (Lo 2019) suggests selection for Kindleberger cycle-prone institutions.

Economic selection is multilevel (Nelson and Winter 1982), pitting individuals against individuals, firms against firms, and economies against economies, and higher-level often defeat lower-level selection. IBM dominated computers until the 1980s, when its top executives, all mainframe engineers, opposed microcomputers to safeguard their positions, won the competition between individuals within IBM, but saw IBM sidelined in firm-level competition (Betz 1993). In a similar vein, Rosenberg and Birdzell (1986, pp. 136-9) describe competition between nations suppressing Cardwell's Law. 
"In the West, the individual centers of competing political power had a great deal to gain from introducing technological changes that promised commercial or industrial advantage . ... Once it was clear that one or another of these competing centers would always let the genie out of the bottle, the possibility of aligning political power with the economic status quo and against technological change more or less disappeared from the Western mind".

Nineteenth-century mania investors ruined by financing canal, railway and telegraph networks (Standage 1998) gave governments more productive economies to tax in the long run. Mania-financed technologies also had direct military spillovers. Railways accelerated troop movements and intelligence transmission from the speed of horses to those of locomotives and electricity. France, having dampened stock speculation after the Mississippi bubble (Murphy 2005), had only 750 miles of telegraph wire by 1852 (Gross 2007). Proliferating loopholes in Britain's contemporaneous Bubble Act allowed successive stock market manias to generate tax revenues to sustain a Royal Navy that soon ruled the waves.

Economic selection is fast. Natural selection is Darwinian: the unfit die, the fit survive and procreate. Economic selection is Lamarckian: the unfit imitate the fit. Heuristics spread without individuals, firms or economies dying. Stock market manias spread from country to country, spreading the positive externalities of new technologies, abetted by governments failing to enforce foreign patents. ${ }^{17}$

Economic selection can jump. Natural selection moves in small increments that find local optima. Cephalopod eyes are better designed than vertebrate eyes, whose blood supply is on the wrong side of the retina (Lents 2018). Because no sequence of small improvements leads from one to the other, humans cope with second-class eyes. In contrast, Kindleberger cycles and capital floods can raise entirely new technologies and wash away old ones. No sequence of small improvements led from horses to automobiles; nor from backward Tokugawa Japan to Asia's first industrialized economy (Morck and Nakamura 2005). Both transformations were large discrete jumps.

In these ways, economic selection can do what natural selection cannot. Multilevel economic competition may thus do far more than eliminate dead-weight losses of standard economic models. Economic selection for institutions conducive to Kindleberger cycles may suppress Cardwell's Law.

\section{Capital Hydraulics}

Irving Fisher build a model economy of pipes, pumps, valves, floaters and reservoirs of aqueous capital that inspired general equilibrium microeconomics (Brainard and Scarf 2005). Several seemingly disconnected streams of research suggest Kindleberger cycles induce periodic inundations of capital that

17 See Harris (2017), also Andreas (2013), Bliss (1987), and Morck and Nakamura (2005) on specific American, Canadian, and Japanese government policies. 
increase the total capacity of that plumbing. As annual Nile floods renewed Egypt, intermittent capital inundations may renew the prosperity of the modern world. For centuries, irregularly repeating Kindleberger cycles suppressed Cardwell's Law, permitting ever-larger positive externalities from innovation, and ever-increasing long-run prosperity.

To end annual flood damage, Egypt erected the Aswan dam and adopted chemical fertilizers. Ending capital floods seems untenable: intellectual property rights and subsidies to innovators often work poorly. Until economic selection finds something better, leading economies are likely to be those that permit Kindleberger cycles because economies that do not are likely to fall behind. Meanwhile, Kindleberger cycles are likely to remain a fundamental advantage, rather than a troubling flaw, of successful free-market economies and policy-makers might seek to attenuate their social costs and accentuate their social benefit. 


\section{Figure 1. Solow residual versus $R \& D$ spending}

Economies with higher research and development (R\&D) spending have faster economic growth primarily because they show evidence of greater cumulative multifactor productivity growth (one proxy for Solow Residuals). Greater productivity growth reflects the faster and more complete adoption of new technologies, which let firms produce ever more valuable outputs from given inputs.

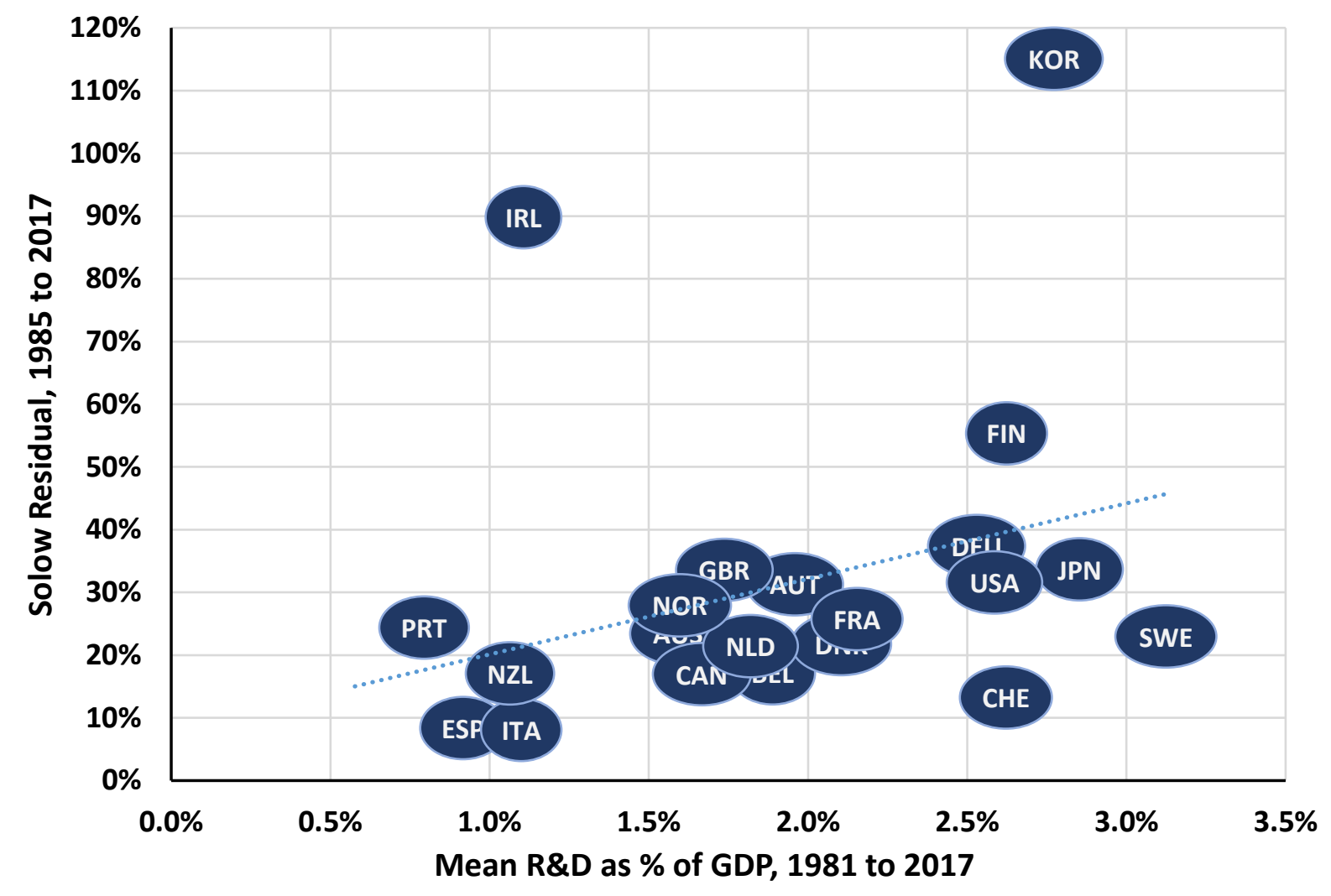

Source: $\underline{\text { OECD data website. }}$ 


\section{Figure 2. Social and Private Returns to Research and Development (R\&D) over Time}

The social and private returns to aggregate US R\&D (red and blue, respectively, with $95 \%$ confidence intervals shown)) compared to cost-of-capital benchmarks for successively higher systematic risk (successively lighter green dotted lines) investments

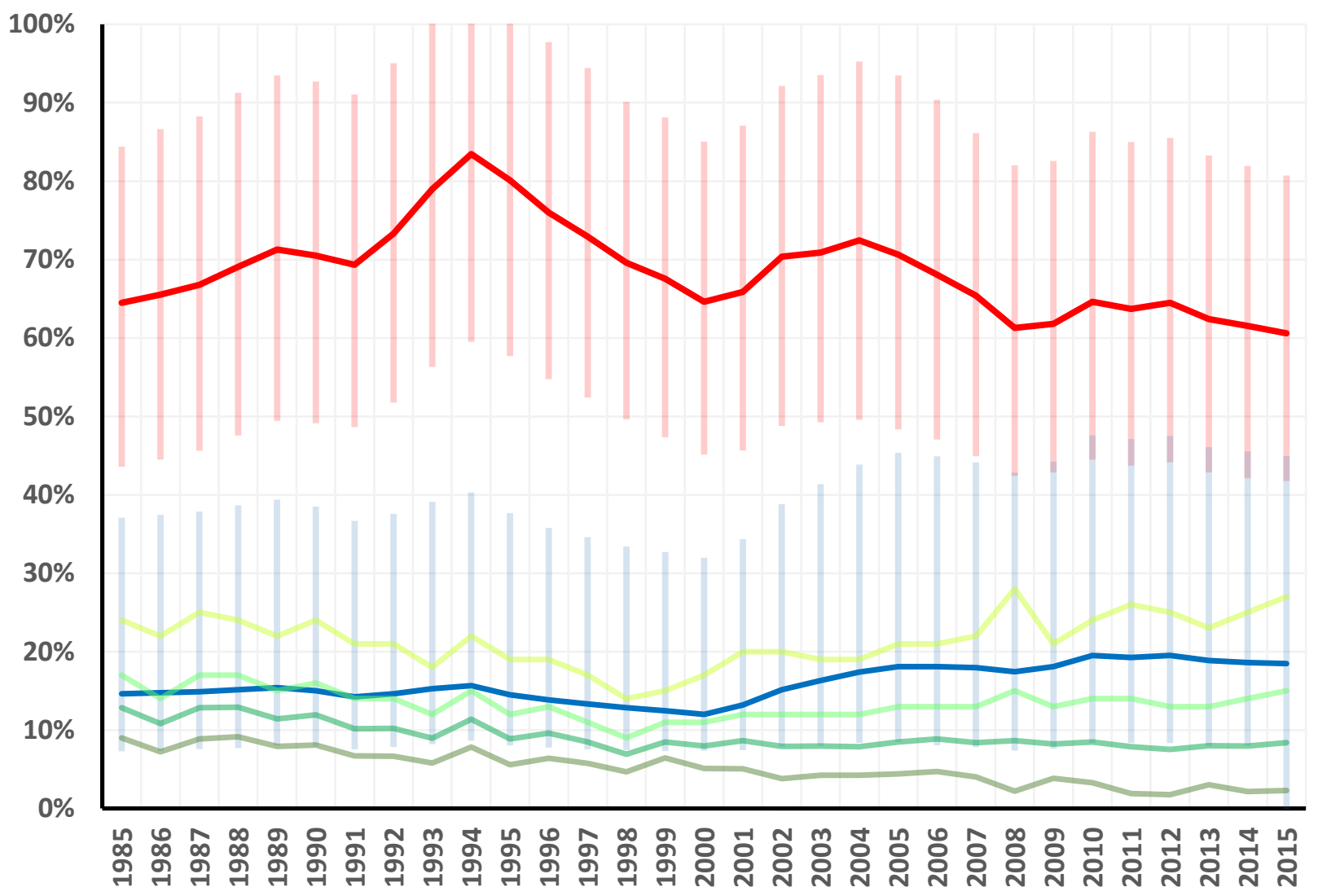

Source: Social and private R\&D returns are from Lucking et al (2019), approximated as described in the online appendix to Bloom et al (2013), with thin lines above and below each delimiting 95\% confidence bounds. Successively lighter green lines denote cost of capital benchmarks, ranging from the T-bond rate for R\&D without significant systematic risk (Jørring et al. 2017) to that plus the market risk premium for ventures with risk typical of generic stocks, plus double the equity risk premium for high-risk ventures (Damodaran 2014), and plus fourfold the equity risk premium for extreme risk venture (Welch 2020). 


\section{Figure 3. Kindleberger Cycle Growth Engine}

Kindleberger describes a historical cycle of financial manias, panics, and crashes following a common pattern, each preparing the way for the next, and most rolling out major new technologies or markets with large productivity-increasing positive externalities. Each completion of the cycle ratchets productivity up to a higher baseline level after the economy recovers from the panic and crash.

\section{Elevated Baseline}

Investors earn equilibirum risk-adjusted returns. If social benefits of the mania > social costs of the panic and crash, the economy attains higher baseline

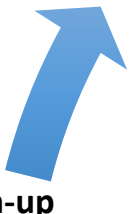

\section{Clean-up}

Unsophisticated investors lose money, default on loans \& blame regulators. Governments bail out banks, some governments then default. Tough new regulations

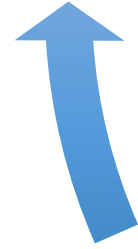

Panic \& Crash

Expecting asset prices to fall, each uninformed trader want to sell first. A "run" to sell first causes stock prices to crash suddenly.

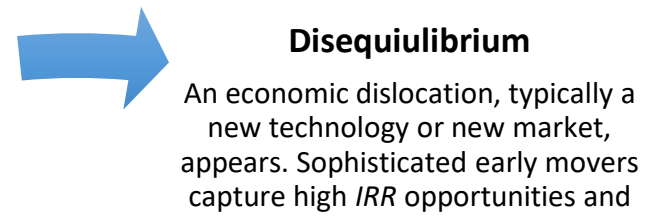

grow rich

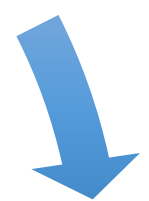

Credit expansion \& deregulaton

Uninformed investors seeing others grown rich, demand increrased credit \& deregulation.

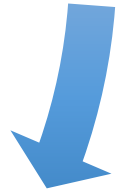

Bubble

Positive feedback creates a bubble capital inflow raises stock prices, which attracts more capital, which rasies stock prices ... Capital floods into new high SRR technologies or markets

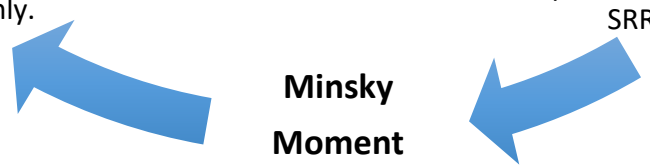

The bubble bursts 


\section{References}

Acharya R. 2008. Private \& Social Rates of Returns to R\&D In OECD Countries: How Different Are They Across Industries? Industry Canada Working Paper 2008-04

Acharya V \& Xu Z. 2017. Financial dependence \& innovation: The case of public versus private firms. Journal of Financial Economics 124(2)223-243.

Aghion P, Askenazy P, Berman N, Cette G \& Eymard, L. 2012. Credit constraints \& the cyclicality of R\&D investment: Evidence from France. Journal of the European Economic Association 10(5)1001-24.

Ahmadpoor M \& Jones BF. 2017. The Dual Frontier: Patented Inventions and Prior Scientific Advance. Science $357,583-87$.

Akcigit U \& Nicholas T. 2019. History, Micro Data \& Endogenous Growth. Annual Review of Economics 11 615-33

Akerlof GA \& RJ Shiller.2010. Animal spirits: How human psychology drives the economy \& why it matters for global capitalism. Princeton University Press.

Ales L, Cho SH \& Körpeoğlu E. 2017. Optimal award scheme in innovation tournaments. Operations Research 65(3)693-702.

Aliber RZ \& Kindleberger CP. 2015. Manias, Panics, and Crashes. Palgrave Macmillan.

Allen F. 2001. Financial Structure \& Financial Crisis. International Review of Finance 2(1)1-19

Andreas P. 2013. Smuggler nation: how illicit trade made America. Oxford University Press.

Angeletos GM, Lorenzoni G \& Pavan A.2010. Beauty Contests \& Irrational Exuberance: A Neoclassical Approach. NBER w15883.

Ashton TS. 1948. The Industrial Revolution, 1760-1830. Oxford University Press.

Azoulay P, Greenblatt WH \& Heggeness ML, 2021. Long-term effects from early exposure to research: Evidence from the NIH. Research Policy 50(9)1

Azoulay P, Zivin JG \& Li D. 2019. Public R\&D Investments and Private-sector Patenting: Evidence from NIH Funding Rules. Review of Economic Studies 86(1)117-152

Balen M. 2002. A Very English Deceit: The Secret History of the South Sea Bubble \& the First Great Financial Scandal. Fourth Estate, London.

Baptist EE. 2014. The Half Has Never Been Told: Slavery \& the Making of American Capitalism. Civitas

Barone M. 2007. Our First Revolution: The Remarkable British Uprising That Inspired America's Founding Fathers. Crown, New York.

Barsade SG. 2002. The ripple effect: Emotional contagion \& its influence on group behavior. Administrative Science Quarterly 47(4)644-75.

Baumol WJ. 1990. Entrepreneurship: Productive, Unproductive \& Destructive. Journal of Political 
Economy 98(5)893-921.

Beason R, Weinstein D. 1996. Growth, economies of scale, and targeting in Japan (1955-1990). Review of Economics and Statistics 78(2)286-295

Bekar C, Carlaw K \& Lipsey R. 2018. General-purpose technologies in theory, application \& controversy: a review. Journal of Evolutionary Economics 28(5)1005-33.

Bernanke BS. 1983. Nonmonetary Effects of the Financial Crisis in the Propagation of the Great Depression. American Economic Review 73(3)257-276.

Betz F. 1993. Strategic Technology Management. McGraw Hill

Bikhchandani S, Hirshleifer D \& Welch I. 2006. Information Cascades and Observational Learning. New Palgrave Dictionary of Economics. Palgrave Macmillan.

Bikhchandani S, Hirshleifer D, Tamuz O \& Welch I. 2021. Information Cascades \& Social Learning. NBER w28887.

Bissonnette Z. 2016. The Great Beanie Baby Bubble: Mass Delusion \& the Dark Side of Cute. Portfolio Blackmore S. 1999. The Meme Machine. Oxford University Press

Bliss M. 1987. Northern Enterprise. Macmillan.

Bloom N, Jones CI, Van Reenen J \& Webb M. 2020. Are ideas getting harder to find? American Economic Review 110(4)1104-44

Bloom N, Schankerman M \& Van Reenen J. 2013. Identifying technology spillovers and product market rivalry. Econometrica 81(4)1347-93.

Bolt J \& van Zanden JL. 2020. Maddison style estimates of the evolution of the world economy. Groningen Growth \& Development Centre.

Bolton P, Santos T \& Scheinkman JA. 2011. Outside and inside liquidity. Quarterly Journal of Economics 126(1)259-321.

Bordalo P, Gennaioli N, Kwon SY \& Shleifer A. 2021. Diagnostic bubbles. Journal of Financial Economics 141(3)1060-77.

Bordalo P, Gennaioli N, Ma Y \& Shleifer A. 2020. Overreaction in macroeconomic expectations. American Economic Review 110(9)2748-82.

Bosi S \& Pham NS. 2016. Taxation, bubbles \& endogenous growth. Economics Letters 143(1)73-6.

Bošković B, Byrne DP \& Magesan A. 2013. Herding among bureaucrats. SSRN 2085042

Brainard W \& Scarf HE. 2005. How to compute equilibrium prices in 1891. In Dimand RW \& Geanakoplos J, eds. Celebrating Irving Fisher. Oxford University Press.

Bremermann HJ. 1962. Optimization through evolution \& recombination. In Yovitts MC et al, eds. Selforganizing systems. Spartan, 93-106.

Bresnahan TF \& Trajtenberg M. 1995. General purpose technologies: Engines of growth? Journal of 
Econometrics 65(1)83-108.

Brown JR \& Petersen BC. 2011. Cash holdings \& R\&D smoothing. Journal of Corporate Finance 17(3)694-709.

Brown JR, Martinsson G \& Petersen BC. 2012. Do financing constraints matter for R\&D? European Economic Review 56(8)1512-29.

Brown JR, Martinsson G \& Petersen BC. 2017. What promotes R\&D? Comparative evidence from around the world. Research Policy 46.2 447-462.

Brown JR, Fazzari SM \& Petersen BC. 2009. Financing innovation \& growth: Cash flow, external equity $\&$ the 1990s R\&D boom. Journal of Finance 64(1)151-185.

Burke E. 1790, Reflections on the Revolution in France. Dodsley.

Caballero R \& Jaffe A. 1993. How high are the giants' shoulders? An empirical assessment of knowledge spillovers \& creative destruction in a model of economic growth NBER Macroeconomics Annual 1993(1)15-73

Campbell G. 2012. Myopic rationality in a mania. Explorations in Economic History 49(1)75-91.

Campbell G. 2013. Deriving the railway mania. Financial History Review 20(1)1-27.

Cardwell DSL. 1972. Turning Points in Western Technology. Neale Watson, NY

Carswell J. 1993. The South Sea Bubble. Sutton.

Chancellor E. 1999. Devil Take the Hindmost: A History of Financial Speculation. Farrar, Straus, Giroux NY

Chen K \& Wen Y. 2017. The great housing boom of China. American Economic Journal: Macro 9(2)73114

Choi J. 2018. The rise of 3D printing \& the role of user firms in the US: evidence from patent data. Technology Analysis \& Strategic Management 30(10)1195-209.

Cole J. 1720. Devil Take the Hindmost. London \& Westminster: London

Dagher J. 2018. Regulatory Cycles: Revisiting the Political Economy of Financial Crises. IMF

Damodaran A. 2014. Equity risk premiums: Determinants, estimation \& implications. Author's website NYU Stern School of Business.

Dang TV \& Xu Z. 2018. Market sentiment and innovation activities. Journal of Financial \& Quantitative Analysis 53(3)1135-61.

Davenant C. 1701. The True Picture of a Modern Whig. Rooke:Bath

Davids K. 2015. The Longitude Committee \& the practice of navigation in the Netherlands, c. 17501850. In Davids K, ed. Navigational Enterprises in Europe \& its Empires, 1730-1850. Palgrave Macmillan, London, 32-46.

Deaton A. 2013. The Great Escape. Princeton University Press. 
Demirgüç-Kunt A and Levine R. 2018. Finance and Growth. Elgar

Diamond DW \& Dybvig PH. 1983. Bank runs, deposit insurance \& liquidity. Journal of Political Economy 91(3)401-19.

Dicks D \& Fulghieri P. 2021. Uncertainty, investor sentiment \& innovation. Review of Financial Studies 34(3)1236-79

Drahos P. 2003. Global law reform \& rent-seeking: The case of intellectual property. Australian Journal of Corporate Law 7(1)1-17.

Easterly W. 2006. The White Man's Burden: Why the West's Efforts to Aid the Rest Have Done So Much Ill \& So Little Good. Penguin

Eatwell J. 2004. Useful bubbles. Contributions to Political Economy 23(1)35-47.

Edgerton D. 2004. The linear model did not exist. In Grandin K \& Wormbs N, eds. The Science-Industry Nexus. Wats:NY 1-36.

Epstein LG \& Schneider M. 2010. Ambiguity \& asset markets. Annual Review of Financial Economics 2 $315-46$

Ewens M, Jones C \& Rhodes-Kropf M. 2014. The price of diversifiable risk in venture capital \& private equity. Review of Financial Studies 26(8)1854-89

Fahlenbrach R, Prilmeier R \& Stulz RM. 2018. Why does fast loan growth predict poor performance for banks? Review of Financial Studies 31(3)1014-63.

Fazio C, Guzman J \& Stern S. 2019. The impact of state-level R\&D tax credits on the quantity \& quality of entrepreneurship. NBER. w26099.

Field A. 2003. The most technologically progressive decade of the century. American Economic Review 93(4)1399-414

Field A. 2011. A Great Leap Forward: 1930s Depression \& U.S. Economic Growth. Yale University Press,

Fohlin C. 2005. Corporate Finance and Governance in the German Industrialization. Cambridge

Frehen RGP, Goetzmann WH \& Rouwenhorst KG. 2013. New evidence on the first financial bubble. Journal of Financial Economics 108(3)585-607.

Frentrop P. 2002. A History of Corporate Governance, 1602-2002. Diminor

Galor O \& Michalopoulos S. 2012. Evolution \& the growth process: Natural selection of entrepreneurial traits. Journal of Economic Theory, 147(1)759-780.

Geanakoplos J. 2010. The leverage cycle. NBER Macroeconomics Annual 24(1)1-66.

Gibson RM. \& Hoglund J. 1992. Copying \& Sexual Selection. TREE 7(7)229-232.

Gillispie CC. 1960. The Edge of Objectivity: An Essay in the History of Scientific Ideas. Princeton University Press. 
Goldfarb B \& Kirsch DA. 2019. Bubbles \& crashes: The Boom \& Bust of Technological Innovation. Stanford University Press.

Goldgar A. 2008. Tulipmania: Money, Honor \& Knowledge in the Dutch Golden Age. University of Chicago Press

Gompers PA. \& Lerner J. 1999. The Venture Capital Cycle. MIT Press.

Goolsbee A. 1998. Does government R\&D policy mainly benefit scientists \& engineers? American Economic Review 88(2)298-302.

Gordon RJ. 2015. Secular stagnation: A supply-side view. American Economic Review 105(5)54-59.

Gordon RJ. 2016. The Rise \& Fall of American Growth. Princeton University Press.

Greenwood R, Hanson SG, Shleifer A \& Sørensen JA. 2020. Predictable financial crises. NBER w27396.

Griliches Z. 1957. Hybrid corn: An exploration in the economics of technological change. Econometrica, 25(4)501-22.

Gross d. 2007. Pop! Why Bubbles Are Great for the Economy. Collins.

Grossman SJ \& Stiglitz JE. 1980. On the impossibility of informationally efficient markets. American Economic Review 70(3)393-408.

Haddad V, Ho P \& Loualiche E. 2020. Bubbles and the Value of Innovation. Federal Reserve Bank of Richmond wp 20-08.

Hall BH, Mairesse J \& Mohnen P 2010. Measuring the returns to R\&D. In Hall BH \& Rosenberg N eds. Elsevier Handbook of the Economics of Innovation. Elsevier.

Harris JR.2017. Industrial Espionage \& Technology Transfer: Britain \& France in the 18th Century. Taylor \& Francis

He JJ \& Tian X. 2020. Institutions \& innovation. Annual Review of Financial Economics 12 377-398

Heller M \& Eisenberg R. 1998. Can patents deter innovation? The anticommons in biomedical research. Science 280(5364)698-701.

Hirano T \& Yanagawa N. 2016. Asset bubbles, endogenous growth \& financial frictions. Review of Economic Studies 84(1)406-43.

Hirshleifer, D. 2015. Behavioral finance. Annual Review of Financial Economics 7 133-59

Hong H. \& Stein JC. 2007. Disagreement \& the stock market. Journal of Economic Perspectives 21(2)109-28.

Horgan J. 1996. The End of Science: Facing the Limits of Knowledge in the Twilight of the Scientific Age. Addison-Wesley

Hsu PH, Tian X \& Xu Y. 2014. Financial development \& innovation: Cross-country evidence. Journal of Financial Economics 112(1)116-35.

Ioannidis JPA, Greenland S, Hlatky MA, Khoury MJ, Macleod MR, Moher D, Schulz KF \& Tibshirani R. 
2014. Increasing value $\&$ reducing waste in research design, conduct $\&$ analysis. Lancet 383(9912)166-175.

Jaffe AB \& Lerner J. 2011. Innovation \& its discontents: How our broken patent system is endangering innovation \& progress \& what to do about it. Princeton University Press

Jaffe AB. 1989. Real effects of academic research. American Economic Review 79(5)957-970.

Janeway WH. 2018. Doing Capitalism in the Innovation Economy, $2^{\text {nd }}$ ed. Cambridge University Press.

Janeway WH, Ramana N \& M Rhodes-Kropf. 2021. Venture Capital Booms \& Start-Up Financing.

Annual Review of Financial Economics 13 111-27

Jarrow RA. 2015. Asset Price Bubbles. Annual Review of Financial Economics 7 201-18

Jones SE. Against Technology: From the Luddites to neo-Luddism. Routledge, 2013.

Jones BF \& Summers LH. 2022. A calculation of the social returns to innovation. In Goolsbee A \& Jones BF, eds. Innovation \& Public Policy. University of Chicago Press.

Jones C \& Williams J. 1998. Measuring the social rate of return to R\&D. Quarterly Journal of Economics 113(4)119-35.

Jorda O, Schularick DM \& Taylor A. 2013. When credit bites back: Leverage, business cycles \& crises. Journal of Money, Credit and Banking 45(s2)3-28

Jørring A, Lo AW, Philipson TJ, Singh M, Thakor RT. 2017. Sharing R\&D risk in healthcare via FDA hedges. NBER wp 23344.

Juma C. 2016. Innovation \& its Enemies. Oxford University Press,

Kahneman D \& Tversky A. 2013. Prospect theory: An analysis of decision under risk. Handbook of the Fundamentals of Financial Decision Making. 99-127.

Kahneman D. 2011. Thinking, Fast \& Slow. Farrar, Straus \& Giroux.

Kaminsky GL \& Reinhart CM. 1999. The twin crises: The cause of banking \& balance of payment problems. American Economic Review 89(1)473-500

Kapeller J \& Schütz B. 2014. Debt, boom, bust: a theory of Minsky-Veblen cycles. Journal of Post Keynesian Economics 36(4)781-814.

Katz ML. \& Shapiro C. 1985. Network externalities, competition \& compatibility. American Economic Review 75(3)424-40.

Kelly B, Papanikolaou D, Seru A \& Taddy. 2021. Measuring technological innovation over the long run. American Economic Review: Insights 3(3)303-20

Kerr WR, Nanda R \& Rhodes-Kropf M. 2014. Entrepreneurship as experimentation. Journal of Economic Perspectives 28(3)25-48.

Keynes JM. 1936. The General Theory of Employment, Interest \& Money. London: Macmillan.

Kindleberger CP. 1978. Manias, Panics \& Crashes: A History of Financial Crises. Basic. 
King M \& Kay J. 2020. Radical Uncertainty. Norton.

Kogan L \& Papanikolaou D. 2019. Technological innovation, intangible capital \& asset prices. Annual Review of Financial Economics 11 221-42

Kogan L, Papanikolaou D, Seru A \& Stoman N. 2017. Technological innovation, resource allocation \& growth. Quarterly Journal of Economics 132(2)65-712.

Kremer M. 1998. Patent buyouts: A mechanism for encouraging innovation. Quarterly Journal of Economics 11(4)1137-67.

Krishnamurthy A \& Muir T. 2016. How Credit Cycles across a Financial Crisis NBER wp 28350

Kwak J. 2017. Economism: Bad Economics \& the Rise of Inequality. Pantheon

Lach S \& Schankerman M. 2004. Royalty sharing \& technology licensing in universities. Journal of the European Economic Association 2(2) 252-264.

Lach S. 2002. Do R\&D subsidies stimulate or displace private R\&D? Evidence from Israel. Journal of Industrial Economics 50(4)369-90.

Landes D. 1998. The Wealth \& Poverty of Nations London: Abacus

Lansing KJ. 2012. Speculative growth, overreaction \& the welfare cost of technology-driven bubbles. Journal of Economic Behavior \& Organization 83(3)461-83.

Lansing K. 2009. Speculative bubbles \& overreaction to technological innovation. Journal of Financial Transformation 26(1)51-4.

Lents NH. 2018. Human Errors. Houghton Mifflin Harcourt,

Lerner J. 2009. Boulevard of Broken Dreams. Princeton University Press.

Levy-Eichel M. 2015. Into the Mathematical Ocean: Navigation, Education \& the Expansion of Numeracy in Early Modern England \& the Atlantic World. Yale University press

Liebowitz SJ \& Margolis SE. 1994. Network externality: An uncommon tragedy. Journal of Economic Perspectives 8(2)133-50.

Lo AW \& Remorov A 2021, Algorithmic models of investor behavior. Journal of Systematic Investing 1(1)1-29.

Lo AW. 2019. Adaptive Markets: Financial Evolution at the Speed of Thought. Degruyter

Lucas D. 2019. Measuring the cost of bailouts. Annual Review of Financial Economics 11 85-108.

Lucking B, Bloom N \& Van Reenen J, 2019. Have R\&D spillovers declined in the $21^{\text {st }}$ century? Fiscal Studies 40(4)561-90.

Mackay C. 1841. Extraordinary Popular Delusions \& the Madness Of Crowds. London: Bentley.

Martin A \& Ventura J. 2010. Economic growth with bubbles. American Economic Review 102(3)95-100

Martin A \& Ventura J. 2018. The macroeconomics of rational bubbles: a user's guide. Annual Review of Economics 10 505-539. 
Mazur A.. 1975. Opposition to technological innovation. Minerva, 13(1)58-81.

McGinnis PJ. 2020. Fear of Missing Out: Practical Decision-Making in a World of Overwhelming Choice. Sourcebooks.

Minsky HP. 1986. Stabilizing an Unstable Economy. Yale University Press.

Moeller SB, Schlingemann FP \& Stulz RM. 2005. Wealth destruction on a massive scale? A study of acquiring-firm returns in the recent merger wave. Journal of Finance 60(2)757-82.

Mokyr J. 1994. Cardwell's Law \& the political economy of technological progress. Research Policy 23(5)561-74

Mokyr J. 2000. Innovation \& its Enemies: the economic \& political roots of technological inertia. In Olson M \& Kähköhnen S eds. A Not-So-Dismal Science: A Broader View of Economics. Oxford University Press pp 61-91

Mokyr J. 2018. The past \& the future of innovation: some lessons from economic history. Explorations in Economic History 69(1)13-26

Morck RK \& Steier L. 2005. The global history of corporate governance: An introduction. In Morck RK, ed. A History of Corporate Governance around the World. University of Chicago Press, 1-64

Morck RK \& Nakamura M. 2005. A frog in a well knows nothing of the ocean: A history of corporate ownership in Japan. In Morck RK, ed. A History of Corporate Governance around the World. University of Chicago Press, 367-466.

Morck RK \& Nakamura M. 2018. Japan's ultimately unaccursed natural resources-financed industrialization. Journal of the Japanese \& International Economies 47(1)32-54.

Moser P. 2016. Patents \& innovation in economic history. Annual Review of Economics 8 241-58.

Murphy AE. 2005. Corporate Ownership in France: The Importance of History. In Morck RK, ed. A History of Corporate Governance around the World. University of Chicago Press, 185-222.

Needham J. 2004. Science \& Civilisation in China, Volume 7.2. Cambridge University Press

Nelson RR, Dosi G, Helfat CE, Pyka A, Saviotti PP, Lee K, Winter SG, Dopfer K, Malerba F. 2018. Modern evolutionary economics: An overview. Cambridge University Press

Nelson RR \& Winter SG. 1982. An Evolutionary Theory of Economic Change. Harvard University Press.

Nicholas T. 2007. Stock market swings \& the value of innovation, 1908-1929. In Nicholas T, ed. Financing of Innovation in the US 1870 to the Present. MIT Press, 217-45.

Nicholas T. 2008. Does innovation cause stock market runups? Evidence from the great crash. American Economic Review 98(4)1370-96.

Nicholas T. 2010. The role of independent invention in US technological development 1880-1930. Journal of Economic History 70(1)57-82

OECD. 2003. Sources of Economic Growth in OECD Countries. OECD: Paris 
Olivier J. 2000. Growth-enhancing bubbles. International Economic Review 41(1)133-51.

Osullivan M. 2007. The expansion of the US stock market, 1885-1930. Enterprise \& Society 8(3)489542.

Pástor L \& Veronesi P. 2009. Technological revolutions \& stock prices. American Economic Review 99(4)1451-83.

Perez C. 2002. Technological Revolutions \& Financial Capital: The Dynamics of Bubbles \& Golden Ages. Cheltenham: Edward Elgar.

Petram LO. 2011. The World's First Stock Exchange: How the Amsterdam Market for Dutch East India Company Shares Became a Modern Securities Market, 1602-1700. Eigen Beheer.

Phillips GM \& Zhdanov A. 2013. R\&D \& the incentives from merger \& acquisition activity. Review of Financial Studies 26(1)34-58

Pigou AC. 1920. Economics of Welfare. Macmillan.

Reinhart C \& Rogoff K. 2009. This Time Is Different. Princeton University Press.

Rosenberg N \& Birdzell LE. 1986. How the West Grew Rich: The Economic Transformation of the Industrial World. Basic

Rosenstein-Rodan P. 1943. Problems of industrialisation of Eastern \& South-Eastern Europe. Economic Journal 53(1)202-11.

Sachs J \& Warner AM. 2001. Natural resources \& economic development: The curse of natural resources. European Economic Review 45(1)827-83.

Saperstein L. 1997 Copyrights, Criminal sanctions \& economic rents: Applying the rent-seeking model to the criminal law formulation process. Journal of Criminal Law \& Criminology 87(4)1470-510.

Scherer F. 1999. New Perspectives on Economic Growth \& Technological Innovation. Brookings Inst.

Schumpeter JA. 1911. Theorie der wirtschaftlichen Entwicklung. Vienna: Kyklos [Opie R, trans. 1934. Theory of Economic Development, Harvard University Press]

Shiller RJ. 2020. Narrative Economics. Princeton University Press,

Shin JK \& Subramanian C. 2019. Asset price bubbles \& technological innovation. Economic Inquiry 57(1)482-97

Shin Y. 2018. Finance \& economic development in the very long run. Journal of Economic Literature 56(4)1577-86.

Simon HA. 1957. A behavioral model of rational choice. In Simon HA, Models of Man. Wiley.

Simsek A. 2021. The macroeconomics of financial speculation. Annual Review of Economics 13 335-69

Smith A. 1759. The Theory of Moral Sentiments. Millar.

Smith A, Lohrenz T, King J,Montague PR \& Camerer C. 2014. Irrational exuberance and neural crash warning signals during endogenous experimental market bubbles. PNAS 111(1)10503-50 
Sokal A \& Bricmont J. 1999. Fashionable Nonsense: Postmodern Intellectuals' Abuse of Science. Macmillan.

Solow R. 1957. Technical change \& the aggregate production function. Review of Economics \& Statistics 39(3)312-20.

Sorescu A, Sorescu SM, Armstrong WJ \& Devoldere, B. 2018. Two centuries of innovations \& stock market bubbles. Marketing Science 37(4)507-29.

Standage T. 1998. The Victorian Internet. Walker: NY.

Stigler G. 1971. The theory of economic regulation. Bell Journal of Economics \& Management Science 2(1)3-21.

Strevens M. 2013. Herding \& the quest for credit. Journal of Economic Methodology 209(1)19-34.

Sufi A \& Taylor AM. 2021. Financial crises: A survey. NBER wp 29155

Sweeny A. 2009. BlackBerry Planet: The Story of Research In Motion \& the Little Device that Took the World by Storm. Wiley.

Syverson C. 2011. What determines productivity? Journal of Economic Literature 49(2)326-65.

Takao K. 2017. Asset bubbles \& economic growth under endogenous market structure. Macroeconomic Dynamics 1-22.

Tanaka J. 2011. Re-examination of the growth-enhancing bubble. Japanese Economic Review 62(2)17083.

Trajtenberg M. 2018. AI as the next GPT: A political-economy perspective. NBER w24245.

Veblen T. 1899. Theory of the Leisure Class. Macmillan

Watkins WJ. 2014. Patent Trolls: Predatory Litigation \& the Smothering of Innovation. Independent Inst. Welch I. 2020. Simpler better market betas. UCLA working paper.

Williams J \& Taylor E. 2006. The evolution of hyperactivity, impulsivity \& cognitive diversity. Journal of the Royal Society Interface 3(1)399-413.

Wilson DS. \& Wilson EO. 2008. Evolution for the good of the group. American Scientist 96(5)380-89

Wright B. 1983. The economics of invention incentives: patents, prizes \& research contracts. American Economic Review 73(1)691-707.

Wu, T. 2010. The Master Switch: The Rise \& Fall of Information Empires. Knopf, New York.

Zúñiga-Vicente JÁ, Alonso-Borrego C, Forcadell FJ \& Galán JI. 2014. Assessing the effect of public subsidies on firm R\&D investment: a survey. Journal of Economic Surveys 28(1)36-67 